\title{
Flashcard Learning Media to Improve English Vocabulary for Elementary School Students
}

\author{
Mela Fitania, Rahma Puspitarani \\ Universitas Sebelas Maret \\ melafitania09@gmail.com
}

Article History
accepted 24/09/2019 $\quad$ approved 01/10/2019 published 01/12/2019

\begin{abstract}
This article aims to create new innovations in learning media so that learning in elementary schools can run effectively and improve the mastery of English vocabulary. The research method used is literature study. The research method used is a review study of books, literature, notes, and reports relating to the problem being solved. Literature sources in this study were obtained from books, journals, and research results. This research includes the process of identifying theories systematically, finding literature, and analyzing documents that contain information related to the research topic. The result of this study is learning media that can be applied by teachers to achieve learning objectives effectively and improve the mastery of English vocabulary.
\end{abstract}

Keywords: learning media, flashcard, vocabulary

\begin{abstract}
Abstrak
Artikel ini bertujuan untuk menciptakan inovasi baru pada media pembelajaran sehingga pembelajaran di sekolah dasar dapat berlangsung secara efektif dan meningkatkan penguasaan kosakata bahasa Inggris. Metode penelitian yang digunakan adalah studi kepustakaan. Metode penelitian yang digunakan yakni dengan studi penelaahan terhadap buku, literatur, catatan, dan laporan yang berkaitan dengan masalah yang sedang dipecahkan. Sumber kepustakaan dalam penelitian ini diperoleh dari buku, jurnal, dan hasil penelitian. Penelitian ini mencakup proses mengidentifikasi teori secara sistematis, menemukan literatur, dan menganalisis dokumen yang berisi informasi yang berkaitan dengan topik penelitian. Hasil penelitian ini berupa media pembelajaran yang dapat diterapkan oleh guru untuk mencapai tujuan pembelajaran secara efektif dan meningkatkan penguasaan kosakata bahasa Inggris.

Kata kunci : media pembelajaran, flashcard, kosakata
\end{abstract}

Social, Humanities, and Education Studies (SHEs): Conference Series https://jurnal.uns.ac.id/shes

p-ISSN 2620-9284

e-ISSN 2620-9292 


\section{PENDAHULUAN}

Dalam kegiatan belajar mengajar, kesinambungan interaksi antara guru dan murid dapat menentukan seberapa aktif dan menyenangkan suasana belajar di kelas. Dewasa ini siswa dituntut untuk aktif dalam mengikuti pemelajaran. Sedangkan guru perlu untuk terus berinovasi untuk mengembangkan materi serta menyampaikan pemahamannya kepada siswa. Bentuk inovasi yang dapat dilakukan guru adalah dengan memanfaatkan media pembelajaran dalam kegiatan belajar mengajar.

Media pembelajaran yang digunakan dalam kegiatan belajar mengajar di sekolah merupakan salah satu komponen penting untuk mempermudah guru dalam menyampaikan pemahamannya kepada siswa. Menurut Munadi (2013: 7-8), media pembelajaran adalah segala sesuatu yang dapat menyampaikan dan menyalurkan pesan dari sumber secara terencana, sehingga tercipta lingkungan belajar yang kondusif dimana penerimanya dapat melakukan proses pembelajaran secara efisien dan efektif. Menurut Sanaky (2013: 4) media pembelajaran merupakan sarana atau alat bantu pendidikan yang dapat dimanfaatkan sebagai perantara dalam proses pembelajaran untuk meningkatkan efisiensi dan efektifitas untuk mencapai tujuan pengajaran. Dalam arti yang lebih luas, media pembelajaran adalah alat, metode dan teknik yang dimanfaatkan dalam rangka lebih mengefektifkan komunikasi dan interaksi antara pengajar dan pembelajar dalam proses pembelajaran di kelas. Namun berdasarkan penelitian yang telah dilaksanakan oleh Novitasari (2010: 2), sebagian guru lebih senang menerapkan metode ceramah, dan lebih banyak teori daripada praktek. Dalam proses belajar mengajar, siswa diminta menghafalkan beberapa kosakata bahasa Inggris dari kamus ataupun dari buku materi yang ada. Siswa pun menjadi malas untuk belajar sehingga siswa mengalami kesulitan menghafalkan kosakata bahasa Inggris.

Dari pernyataan di atas, dapat disimpulkan bahwa perlu adanya penggunaan media pembelajaran sebagai variasi dalam kegiatan pembelajaran agar perhatian siswa tidak monoton memperhatikan guru menyampaikan materi. Untuk meningkatkan minat siswa terhadap belajar, diperlukan media pembelajaran yang menarik dan inovatif. Selain dapat meningkatkan atensi siswa terhadap materi yang diajarkan, penggunaan media belajar yang menarik dan inovatif dapat memberikan kesan dan kebermaknaan bagi siswa, sehingga materi yang dipelajari lebih mudah dipahami dan diingat. Bentuk pembelajaran menggunakan media fisik sebagai metode komunikasi dapat menyajikan pesan sekaligus merangsang pebelajar untuk lebih konsentrasi dalam pelaksanaan pembelajaran. Dengan bantuan sarana sebagai stimulus untuk menyampaikan pembelajaran, komunikasi antara guru dan siswa akan berjalan dengan lebih baik.

Menurut Novitasari (2010: 21), siswa cenderung mudah mengingat materi yang berupa gambar, animasi, dan suara daripada materi yang disampaikan secara lisan. Berdasarkan pernyataan tersebut, media pembelajaran yang dapat diterapkan adalah media yang berupa visual dan audio. Untuk memudahkan siswa dalam menghafalkan kosakata berbahasa Inggris, salah satu media yang dapat digunakan guru dalam kegiatan belajar mengajar adalah flashcard.

Kasihani (Widya dkk.: 2018) mendefiniskan kosakata atau perbendaharaan kata sebagai jumlah seluruh kata dalam suatu bahasa, yang juga merupakan kata-kata yang dimiliki, diketahui, dan dipakai seseorang dalam berbicara, mendengar, membaca atau menulis. Salah satu media pembelajaran yang dapat meningkatkan vocabulary anak adalah permainan dalam bentuk kartu yang disebut flashcard. Suryana (Hotimah: 2010) mengemukakan bahwa flashcard merupakan salah satu bentuk permainan edukatif berupa kartu-kartu yang memuat gambar dan kata yang sengaja dirancang oleh Doman untuk meningkatkan berbagai aspek diantaranya: mengembangkan daya ingat, melatih kemandirian, dan meningkatkan jumlah kosakata. Satriana (Wardani: 2013) dalam artikelnya, menyatakan bahwa flashcard adalah media pembelajaran 
dalam bentuk kartu bergambar yang berukuran $25 \times 30 \mathrm{~cm}$. Dari beberapa pengertian di atas, dapat disimpulkan bahwa flashcard adalah kartu-kartu bergambar yang memuat kosakata yang digunakan sebagai media pembelajaran edukatif dan dapat mengembangkan daya ingat, melatih kemandirian, dan meningkatkan jumlah kosakata.

Tujuan dilaksanakannya penelitian ini adalah mendeskripsikan media pembelajaran inovatif berbasis permainan flashcard yang efektif dan dapat meningkatkan kosakata bahasa Inggris siswa.

\section{METODE}

Metode yang digunakan dalam penelitian ini yaitu studi kepustakaan, menurut Nazir (2003), mengemukakan bahwa "studi kepustakaan adalah teknik pengumpulan data dengan mengadakan studi penelaahan terhadap buku-buku, literatur-literatur, catatan-catatan, dan laporan-laporan yang ada hubungannya dengan masalah yang dipecahkan." Peneliti melakukan kajian yang berkaitan dengan teori yang berkaitan dengan topik penelitian, mengumpulkan informasi sebanyak-banyaknya dari kepustakaan yang berhubungan.

\section{HASIL DAN PEMBAHASAN}

Widya dkk. (2018) dalam jurnalnya menyatakan bahwa metode dan teknik konvensional memang cukup efektif untuk membantu anak untuk menguasai kosakata, tapi terkadang metode dan teknik tersebut juga menyebabkan kebosanan pada anak karena kurang adanya variasi. Maka dari itu, penggunaan media pembelajaran dapat disebut sebagai variasi dalam metode pengajaran. Vikagustanti (2014: 469) memaparkan kondisi lingkungan yang mendukung menyenangkan dan terbebas dari rasa bosan baik di lingkungan keluarga maupun sekolah pada saat berlangsungnya proses pembelajaran dapat mengantarkan siswa untuk mengekspresikan segala kemampuanya. Dalam jurnalnya, Novitasari (2013: 37) menyampaikan bahwa media yang digunakan harus menarik dan sesuai dengan karakteristik peserta didik agar dapat memotivasi untuk belajar. Aspek kemenarikan ini dapat dilakukan dengan menerapkan teknik belajar sambil bermain.

Dalam penelitian kami, variasi media pembelajaran yang dapat diterapkan oleh guru dalam pembelajaran mata pelajaran bahasa Inggris yaitu flashcard.

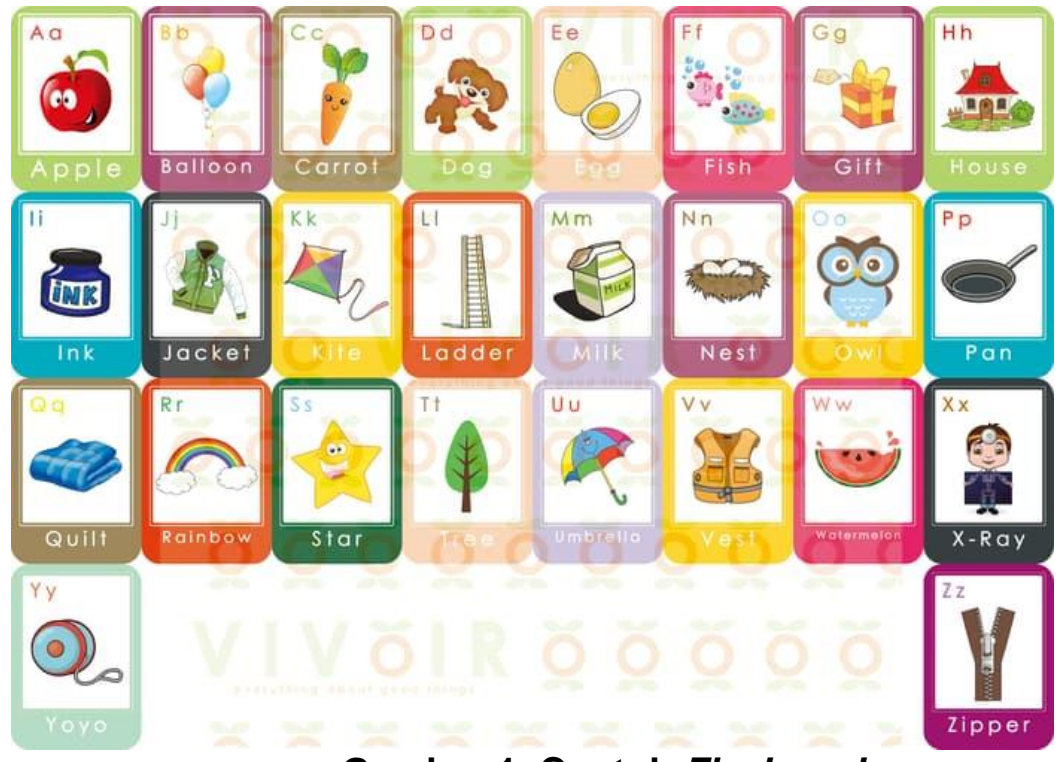

Gambar 1. Contoh Flashcard 
Flashcard termasuk dalam media pembelajaran berupa visual. Dalam bukunya, Khanifatul (2013: 31) mengemukakan bahwa media visual dapat berupa foto, buku, ensiklopedi, majalah, surat kabar, buku referensi, gambar, kliping, transparasi, OHP, sketsa, bagan, grafik, poster, peta, globe, dan masih banyak lagi. Pengajaran akan lebih efektif apabila objek dan kejadian yang menjadi bahan pengajaran dapat divisualisasikan.

Dalam penelitian kami, penggunaan flashcard sebagai media belajar siswa sekolah dasar diterapkan melalui permainan. Guru pengampu mata pelajaran bahasa Inggris menyiapkan sejumlah flashcard berupa kartu bergambar yang terdapat tulisan yang menjelaskan gambar yang tertera pada kartu dan beberapa kertas kosong. Permainan flashcard memiliki beberapa tahapan dan aturan. Pertama-tama, satu kelas dibagi menjadi empat kelompok yang merupakan satu kesatuan dalam permainan. Masing-masing kelompok berbagi peran dan tugas secara bergilir. Ada 4 peran yang harus dipraktekkan setiap kelompok selama permainan berlangsung. Kelompok pertama melakukan pantomim, kelompok kedua bertugas menebak gerakan, kelompok ketiga bertugas menerjemahkan kata ke dalam bahasa Inggris, dan kelompok keempat yang bertugas menulis kata berbahasa Inggris.

Pertama, kelompok yang melakukan pantomim. Salah satu siswa dari kelompok ini dipilih dan melakukan pantomim. Siswa yang terpilih membaca flashcard bertuliskan kata berbahasa Indonesia dan membaca kata dibaliknya yang tertera dalam bahasa Inggris dari kata tersebut. Setelah membaca flashcard, kata tersebut disampaikan kepada temannya oleh siswa yang melakukan pantomim dengan cara mempraktekkan kata tersebut. Misal, kata tersebut bertuliskan "menyapu". Siswa yang melakukan pantomim diberi batasan waktu selama 30 detik untuk mempraktekkan gerakan. Kelompok ini melakukan pantomim mempraktekkan gerakan menyapu kepada temannya yang bertugas menebak gerakan. Jika selama 30 detik siswa yang bertugas menebak gerakan tidak mampu menebak dengan tepat, maka flashcard dilewati (pass) dan lanjut ke flashcard berikutnya. Siswa yang bertugas menjadi pantomim digilir dengan siswa lainnya dalam kelompok ini jika satu flashcard di-pass. Jika gerakan yang dipraktekkan kelompok ini berhasil ditebak oleh kelompok selanjutnya (kelompok kedua), maka kelompok ini mendapatkan 1 poin.

Kedua, kelompok yang bertugas menebak gerakan. Kelompok ini bertugas menebak gerakan yang disampaikan oleh siswa yang melakukan pantomim. Setelah kelompok ini mampu menebak gerakan, kelompok ini menyebutkan gerakan yang dipraktekkan dalam bahasa Indonesia, misal "menyapu". Kelompok ini diberi waktu selama 30 detik untuk menebak gerakan. Kemudian siswa tersebut menyampaikannya kepada kelompok selanjutnya yang bertugas menerjemahkan ke dalam bahasa Inggris. Jika kelompok ini berhasil menebak gerakan dari kelompok pertama, maka kelompok ini mendapatkan 1 poin. Sedangkan jika kelompok ini tidak mampu menebak gerakan dengan tepat, maka flashcard di-pass hingga siswa mampu menebak gerakan yang dipraktekkan kelompok pertama.

Ketiga, kelompok yang menerjemahkan ke dalam bahasa Inggris. Kelompok ini bertugas menerjemahkan kata yang disampaikan oleh kelompok kedua yang menebak gerakan ke dalam bahasa Inggris. Setelah mampu menerjemahkan kata berhasa Indonesia ke dalam bahasa Inggris dengan tepat, kelompok ini menyampaikan kata yang telah diterjemahkan ke dalam bahasa Inggris kepada kelompok selanjutnya yang bertugas menulis kata. Kelompok ini diberi waktu selama 30 detik untuk menerjemahkan kata dari kelompok kedua ke dalam bahasa Inggris. Jika kelompok ini berhasil menerjemahkan kosakata bahasa Indonesia ke dalam bahasa Inggris, maka kelompok ini mendapatkan 1 poin. Jika kelompok ini tidak mampu menerjemahkan kata dalam bahasa Inggris dengan tepat, maka kelompok ini diberi kesempatan untuk menanyakan terjemahan yang tepat kepada kelompok pertama yang melakukan pantomim. 
Keempat, kelompok yang menulis kata berbahasa Inggris. Kelompok ini bertugas menuliskan kata yang disampaikan oleh kelompok ketiga di atas kertas kosong yang telah disediakan oleh guru. Kelompok ini diberi waktu selama 30 detik untuk mendiskusikan dan menuliskan kata berbahasa Inggris. Setelah menuliskan pada kertas kosong, kemudian kertas disetorkan kepada guru. Jika penulisan kata bahasa Inggris tepat, maka satu kelas mendapatkan 1 poin. Namun jika penulisannya salah, maka tidak mendapat poin atau nol.

Setelah satu flashcard dapat terselesaikan, seluruh kelompok bergilir peran. Kelompok pertama bergilir menjadi kelompok kedua, kelompok dua menjadi kelompok ketiga, dan seterusnya.

Aturan dalam permainan flashcard ini diantaranya sebagai berikut.

1. Membagi siswa ke dalam 4 kelompok dengan jumlah yang seimbang.

2. Tiap-tiap kelompok menjalankan 4 peran secara bergiliran antar kelompok.

3. Masing-masing kelompok diberi waktu selama 30 detik untuk melaksanakan tugas dan perannya.

4. Kartu flashcard hanya dapat dilewati atau di-pass oleh kelompok pertama jika kelompok kedua tidak mampu menebak dengan tepat dalam waktu yang diberikan selama 30 detik.

5. Seluruh siswa tidak diperkenankan menanyakan jawaban kepada guru. Jika terdapat siswa yang menanyakan jawaban kepada guru, maka flashcard yang sedang dijalankan hangus dan harus mengulang dari awal dengan flashcard yang baru.

Manfaat utama dari permainan ini adalah menambah kosakata berbahasa Inggris dengan metode fun learning yang kreatif dan inovatif. Selain mengasah kecerdasan anak, permainan ini juga menanamkan pendidikan karakter yang baik bagi anak. Melalui permainan flashcard ini, siswa diajarkan untuk melatih kekompakan, kerja keras, solidaritas sesama teman, kedisiplinan, kejujuran, menalar, dan tanggung jawab.

\section{SIMPULAN}

Penggunaan media flashcard melalui permainan secara berkelompok memiliki berbagai keunggulan dibandingkan dengan metode pengajaran konvensional dan manfaat untuk siswa, diantaranya :

1. Belajar dengan cara yang lebih menyenangkan. Siswa yang belajar dalam suasana yang menyenangkan akan mampu mengingat materi yang diajarkan dengan lebih baik dibandingkan dengan pembelajaran metode biasa. Karena dengan suasana kelas yang menyenangkan akan dapat memberikan kesan pada anak, sehingga akan terkenang dalam ingatannya.

2. Melatih kerja sama. Dalam permainan berkelompok, siswa dilatih untuk bekerja sama dan kompak dengan anggota kelompok.

3. Melatih fokus. Meskipun pelajaran disampaikan dengan cara permainan, namun selama permainan berlangsung siswa dilatih untuk fokus dalam memecahkan persoalan dalam permainan.

4. Menambah semangat belajar. Karena metode yang digunakan adalah permainan, secara otomatis siswa sekolah dasar yang menyukai permainan akan lebih bersemangat untuk belajar.

Jadi, penggunaan media flashcard dapat meningkatkan keefektifan pembelajaran bahasa Inggris dan mampu meningkatkan penguasaan kosakata bahasa Inggris siswa dengan cara belajar yang inovatif dan menyenangkan. 
DAFTAR PUSTAKA

Hotimah, E. (2010). Penggunaan Media Flashcard dalam Meningkatkan Kemampuan Siswa Pada Pembelajaran Kosakata Bahasa Inggris Kelas II MI Ar-Rochman Samarang Garut (Vol. 4 No. 1). Fakultas Pendidikan Islam dan Keguruan Universitas Garut.

Munadi, Y. (2013). Media Pembelajaran. Jakarta: Referensi.

Khanifatul. (2013). Pembelajaran Inovatif. Yogyakarta: Ar-Ruzz Media.

Nazir, M. (2003). Metode Penelitian. Jakarta: Ghalia Indonesia.

Novitasari, D.R. (2010). Pembangunan Media Pembelajaran Bahasa Inggris Untuk Siswa Kelas 1 Pada Sekolah Dasar Negeri 15 Sragen (Vol. 2 No. 1). Universitas Surakarta.

Novitasari, E. dkk. (2013). Pengembangan Media Pembelajaran Berbasis It Berbentuk Permainan Ular Tangga Materi Alat Optik untuk Kelas VIII SMP. Universitas Sebelas Maret.

Sanaky, H.A.H. (2013). Media Pembelajaran Interaktif-Inovatif. Yogyakarta: Kaukaba Dipantara.

Sudjana, N. \& Rivai, A. (2013). Media Pengajaran. Bandung: Sinar Baru Algensindo.

Vikagustanti, D.A. dkk. (2014). Pengembangan Media Pembelajaran Monopoli IPA Tema Organisasi Kehidupan Sebagai Sumber Belajar Untuk Siswa SMP. Universitas Negeri Semarang.

Wardani, K.Y.T. dkk. (2013). Penerapan Metode Bilingual Berbantuan Media Flashcard Untuk Meningkatkan Kemampuan Berbahasa Inggris Anak Kelompok B2 Di TK Saiwa Dharma Singaraja. Universitas Pendidikan Ganesha.

Widya, dkk. (2018). Pengajaran Kosakata Bahasa Inggris dengan Media Realia dan Flash Card (Vol. 1 No. 1). Program Studi Pendidikan Bahasa Inggris, Fakultas Bahasa dan Seni, Universitas Indraprasta PGRI. 